\title{
The Changing Role of the Language Teacher/Technologist
}

\section{Connected Learning, Meaningful Collaborations, and Reciprocal Apprenticeships in the Foreign Language Curriculum}

A version of this paper was selected as a Henderson Plenary Award Finalist at the IALLT 2007 Annual Conference.

Barbara Sawhill

Oberlin College

The role of the language teacher/technologist is changing dramatically due to the convergence of internal and external forces that dictate how new technologies can be used for language learning in an institution. These forces include, but are not limited to, the following:

- the fact that social software and collaborative technologies hold extraordinary potential for language teaching and learning,

- the reality that there are specific, user-centric technologies that are now a normative means for our students to communicate, collaborate, and play with their peers,

- the acknowledgement that there are security-oriented institutional constraints imposed upon technologies for teaching and learning in most academic settings that may limit the scope and the range of any technology used for teaching, and finally,

- the analysis of the way in which we teach language and promote cultural literacy in the foreign language classroom.

Social software tools ${ }^{1}$ challenge the language teacher/technologist to examine critically the current pedagogical practices for language teaching. Social software, by its very nature, is about creating communities and connections. These tools require that we question how we teach and what we teach by challenging our beliefs about the value of teacher-centric, classroom-centric learning versus student-centric out-of-class learning.

By adopting these tools and the teaching philosophies they promote, a disjunction is created within many of our institutions between the task of maintaining a secure, closed IT network and our duty to 
remain current and conversant in the tools that are being developed by others and for an open and ever-expanding community of learners.

On campuses across the country, tense conversations between IT administrators, legal counselors, and language teachers are occurring. The teachers wrestle with how these tools can shape the way students learn, how teachers teach, how learning can happen, and how learning can transcend the walls of the classroom and the boundaries of the schedule, the syllabus, and the curriculum. The technology administrators balance the support of these tools with the need to secure and support the network that uses them. Meanwhile, back in the Administration building, administrators worry about compliance to Federal laws and regulations, especially in regards to student privacy and copyright compliance.

By no means a panacea, social software challenges language educators, learning technologists, networking administrators, and legal counsel to come together and to think about the how's and the why's of the learning experience, with the goal of affording its users a journey towards a new level of language proficiency through collaborations between students, teachers, technologists, and the world.

\section{Our students, our teaching, and expectations: demystifying "The Millennials"}

Before we begin to analyze the tools and their challenges for teaching, learning, network security, and potentially The Academy's compliance with the law, let us first begin by reviewing of some of the commonly held assumptions about the community of learners we are teaching. Let us also consider their expectations for the use of technology in the classroom.

Many of our students choose to be connected with their social networks through technology: on the web, via cell phones, and so forth. For our students there is, according to George Siemens (2007), a sense of persistent presence through sending text messages, or "texting," instant messaging, calling, photo sharing, playing multi-user immersive gaming. Our students spend time in what James Paul Gee (2004) calls affinity spaces - fluid, informal learning spaces based on common social interests. When students need an answer, they tap into their Facebook or MySpace network, Craigslist, Yelp, Google, even World of Warcraft, and they do with great ease and speed.

J. J. Duderstadt et al. (2002), when describing the current state of technology in higher education, wrote: the traditional classroom paradigm is being challenged today, not so much by professors... but by our students. Thanks to the efforts of students, educators now have even more social software tools to consider repurposing or harnessing for teaching than they did a brief year ago.

Learning a language is an inherently social activity. If our students are using new tools for their social needs, will they embrace these same tools as part of their academic experience? Can we assume that all students use social networking tools, or want to? And how many students are we talking about? Is this a universal trend, or just a select handful of students that the media has chosen to highlight?

Sarah Lohnes and Charles Kinser studied a group of students in a small liberal arts college and concluded that educators should not make generation-wide assumptions about students: all students are not alike... students hold different beliefs about the role of technology in that experience... given the multiple ways that technology is culturally embedded in the NetGen students lives, we should not make blanket assumptions about its use. (Lohnes \& Kinser 2007).

Not all students who use these tools for their social networking purposes willingly embrace the idea 
of using them for academic purposes. Kelly Sutton, co-founder of Hack College, a technology blog by and for college students, put it this way: Oftentimes professors trying to use technology or plug into the generation using technology fail miserably. It's like, 'Let's make a podcast.' Well, [the question should be] what problem is that podcast solving? My own experience in the classroom supports Sutton's sentiments: I have encountered a great deal of push back from students when they were asked to blog, IM, use Skype ${ }^{\circledast}$ or video chat for academic purposes. There is a distinct sentiment among the students that this is what I do for me, and takes a lot of time for me to maintain these connections as it is, so if you want me to do it for a grade you had better be ready to tell me why. Our students insist that technology in the classroom be used for sound pedagogical reasons - not just because it might been seen as innovative or "cool."

Millennials, Gen-X-ers, Digital Natives... these are all labels that teachers and administrators apply to connote a gaping difference, a vast void between the people who teach and those who are taught. These terms imply a binary that is not only false but also ignorant of difference and of nuance. There are students who are skilled in technology, but there are also those who are not, and the same is true for the individuals who teach them.

Regardless of our proficiency with learning technologies, students and teachers share common goals for the classroom: both groups want good teaching, good learning experiences, and mutual respect. Just as those of us who were growing long hair and wearing sandals in the 70s were a lot more normal than we looked, so apparently are the Millennials. They are, of course, very comfortable with technology... but their desires for and expectations for learning do not seem to differ much from the previous generations. (Haney 2007)

Given the costs of a post secondary education today, students choose courses not only for the academic credits and availability of the course, but also based upon how much time the coursework will require and whether that time will be well spent. If educational technology is involved, and if it is to be used outside of class, students will want to know that it will be utilized wisely and well.

As educators we must prove to our students that their time (and our time) out of class and using technology will be effective. Therefore, language teachers must become conversant in the tools in order to use them effectively in class. Just as language teachers should be proficient in the language, they also need to demonstrate proficiency in the technologies they use and be ready to defend their use (both to academic peers as well as to students) as a viable, pedagogically sound tool for teaching and learning.

\section{Our changing world and our duty to respond}

Over the past few years, several reports have been written that identify a remarkable disconnect between what we do within our classrooms and what is actually needed by our students once they graduate.

The May 2007 special report by the Modern Language Association states that the world today is a dynamic, rapidly changing environment marked by a sense of crisis around what came to be called the nation's language deficit. The report continues by stating that we find ourselves in a world where the United States' inability to communicate with or comprehend other parts of the world has become painfully evident. The same report quotes Daniel Yankelovich (2005), who states that for education to remain relevant, one of the five essential needs over the next ten years will be the need to understand other cultures and other languages. He continues: our whole culture must become less ethnocentric, less patronizing, less ignorant of others, and more at home in the rest of the world. 
In "Remapping the Foreign Language Curriculum," Janet Swaffar and Katherine Arens (2005) address this point by calling our attention to the fact that learning a language also affords the learner a form of cultural literacy. They explain that what empowers individuals to enter societies; to derive, generate, communicate, and validate knowledge and experience; to exercise expressive capacities to engage others in shared cognitive, social, and moral projects; and to exercise such agency with an identity that is recognized by others in the community. Teaching a language is no longer solely about learning verb forms and vocabulary. In our ever-shrinking world teaching must help students develop and facilitate connections, collaborations, and cultural literacies, all of which bring an appreciation and a respect for the world in which the target language is spoken.

Our language students are not only falling short in language and cultural literacies, but are falling behind in other areas as well. In a recent American Association of Colleges and Universities (AAC\&U) report, business professionals were polled about recent college graduates who had just entered the workforce. The conclusion from this survey was that institutions of higher learning are producing graduates who can be employed, and that these are very capable individuals. However, according to this study, these same individuals do not necessarily have the skills to be promoted. Our students leave our schools unable to critically evaluate and synthesize complicated information and without sufficient real-world experiences to prepare them for the messiness of the world after college (AAC\&U 2007).

As language educators in a rapidly changing world, we are experiencing the problem of teaching our students to face a world that is shifting far faster than our lesson plans may anticipate. We also face the problem of preparing our youth for a world that we cannot yet see. This future world may present issues and challenges that our current teaching practices do not even anticipate. How then should our classrooms reflect the need for communication, connection, and collaboration in our society? How can we as teachers best prepare our language students to perform, react, evolve and thrive in the world that awaits them after graduation?

\section{Teaching languages and cultures in the classroom: in pursuit of more contact time}

To know a language means that one has proficiency in the reading, writing, speaking, and listening comprehension of that language. Each proficiency is a separate skill set and is something that can always be improved. Furthermore, affinities for each skill set vary between learners. Where one learner may excel at reading in the target language, another learner may have an innate gift for speaking the language. One's ability to achieve proficiency can be affected by one's learning style. As a result, language teachers have developed multiple means of presenting information to accommodate different learning styles in order to enable students to become proficient in the four skill sets. Learning a second language is not just a skill set that is acquired through the persistence of practice, it involves complex social interactions, that engage the identities of the foreign language learners in ways that have always received very little attention by second language acquisition researchers. (Norton Pierce 1995)

Alice Omaggio Hadley's research reminds us that it takes approximately 720 contact hours to achieve a minimal level of proficiency in a second language, provided that the language learned has a similar structure to that of our native language (Omaggio Hadley 1993). Add to this fact the realization that in a typical classroom of twenty students, meeting three times a week for one hour each meeting, each student will have, on average, two minutes of direct contact time with the language. A quick 
calculation reveals that achieving a minimal level of proficiency requires more time than our formal classroom environment can provide, and that the goal of fluency via The Academy is, at best, a pipe dream.

Social software such as blogs and wikis and even Voice-over-IP tools like Skype ${ }^{\circledast}$ can help educators and students in two ways; first, they can augment needed contact time with the language and allow students a means to continue to connect with the language outside of the classroom and second, these tools offer our students the possibility of authentic, dynamic contact with native speakers, and therefore the challenge of putting that which is learned in the classroom to the test in a context that mirrors, but does not duplicate, the real world, the real culture, the reality that awaits them outside of The Academy.

\section{Blogs in and out of the classroom}

Blogs are a very popular and mainstream social software that can be used to promote language proficiency and cultural awareness in the classroom... and beyond. Blogs allow our students to participate in a dynamic learning collaborative, following the apprenticeship model of learning outlined by Pierre Lévy (1997), where information is shared, acquired, questioned, analyzed, and discussed together. The blog provides a place where all of the voices in the room (or the blogging community) are valued, and where no one voice is stronger, louder, or more overbearing than another (which can indeed happen in the classroom). When used wisely and well, blogs help students become compassionate readers, writers, and listeners in a second language as well. Using these tools to promote collaborative learning and participation in a respectful creation of community expression, our teaching becomes more democratic and action-centered. The use of blogs in the language classroom allows for an appreciation of the individual and also an appreciation of that individual within the world that speaks the languages we teach and the world in which our students will eventually have to exist and coexist with the language skills we are trying to help them acquire.

Students cannot learn a language in isolation and they need opportunities for interacting, making and correcting their mistakes, communicating within a community that is supportive, engaging, and encouraging. If a community is created and nurtured within the face-to-face classroom, then blogs can reinforce that community and the learning it creates outside of the classroom. We can learn without effort if we are interested in what we are doing (or what someone else is doing), free from confusion, and given assistance when we seek it. [...] You learn in communities of people who do what you are expected to learn. (Smith 1998)

For security and privacy reasons, or because of mandates from the institutions, many teachers chose to use blogs behind a password and only with the members of the class. I would argue that practices such as these, while prudent, dramatically limit the teaching and learning potential that blogs can offer the foreign language curriculum. What follows here are examples of how students in my classes have carefully, conscientiously, and effectively used blogs to communicate with the outside world, and in turn, have enriched not only their own learning, but also the learning of their classmates, their teacher, and their correspondents, in the process.

Blogs can be structured in whatever way suits the content of the class being taught. For my Spanish class, I chose to have a "mother blog" called el blog central that would serve as the opening page for the class and off of which my students' blogs would be linked via a "blogroll." Their blogs, which could be shaped and constructed to their liking, also have blogrolls that would link back to el blog central as well as 


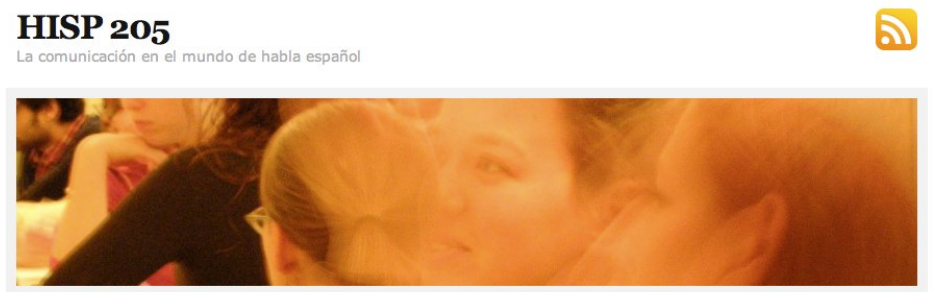

Image 1: El blog central: http://languages.oberlin.edu/hisp205/

We use the WordPress (http://wordpress.com) blogging environment and the "multiple author" feature for the language blogs at Oberlin. Students were given complete control of the backend or the "dashboard" on their blogs and instructed how to use it. They learned quickly how even their own classmates' comments needed to be vetted and approved before appearing, thus reducing the possibility for spam or "flaming" to appear on their blog without their direct approval. For students who wanted more privacy, perhaps when they wrote a particularly personal blog post, it was possible to password protect that unique post and give the password to their classmates.

The first blog post is always the most difficult to create, but soon students realized that the more they wrote (or recorded, since audio and video could be embedded into the posts) the easier the process became but also how quickly previous posts sank into the recesses of the blog (blog posts appear in reverse chronological order, the most recent post appearing on top, the oldest post appearing at the bottom or on a previous page). As a language teacher, I appreciated the longitudinal nature of the tool. The blogs became a ribbon-like portfolio of the students' work, one post after another, each building in length and complexity as time passed.

In fact, the amount and the quality of writing that my students produced over the course of a semester was remarkable, especially when one considers that this was a conversation course and their posts were not individually graded. Equally remarkable was the length and the quality of the comments that my students received from the outside world.

The objective for using a blog in the conversation class is to have students write, to keep writing, to feel encouraged to write more. I chose to use blogs for two reasons. First, because of my belief that the more a student writes in the second language (L2), the more quickly that student will develop proficiency in the language. Second, research is starting to demonstrate that there is a carry-over effect from informal online writing to speaking skills. Researchers are now focusing on how participating in online writing activities can helps student develop oral proficiency (Payne \& Whitney 2002).

\section{Errors, grammar correction, and spelling}

My students were encouraged to write and self correct, or ask for guidance before posting to their blogs. However I did not correct nor grade their writing once it was posted. This practice may seem 
outrageous and even blasphemous to some language teachers. Is that not our job as teachers? Won't those errors fossilize if not corrected on the spot?

My response to these concerns is that I consider my students' errors in the context of the conversation that is evolving within the blog. Are the errors so serious such that they obscure meaning? If so, or if a post begs clarification, what might be the most effective and encouraging way to help the student address those errors and yet keep writing, keep creating in the language? Just as we might do in the classroom, asking questions that model the correct grammatical form in a comment to a student's post allows a less stressful means of improving language but all the while continuing the conversation.

The language that our students create via individual posts should not be judged as discrete, staccato moments. Blogs, when used effectively for language study, should be seen as a portfolio, a collection of thoughts, or posts, that grow and deepen in complexity and intensity over time.

A final word about errors: we need to remind ourselves that even native speakers make errors in their own language, as do we in our own language. Blogs allow us to see language created in all of its forms, the perfect, the imperfect, the bold, and the weird.

\section{Example from a student's blog}

One student, Jenny, starts the conversation with a long post about the movie Secuestro Express which receives a comment from her teacher, and then a native speaker. Notice how Jenny then engages both commenters in her reply, responding to their comments and queries. 
Sawhill

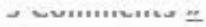

日 Comment by barbara | 2008-02-26 22:47:03

Jenny:

Te felicito por haber escrito esta entrada. Por un lado me alegro de que la película te haya afectado tanto, pero por otro lado me da tristeza de que te haya causado tanta angustia.

Es cierto que estas cosas, aunque muy dificiles y muy feas, ocurren en muchas partes del mundo...hasta nuestro propio pais. El hecho de que estamos tan lejos de estas cosas pero a la misma vez tan cerca también es muy inquietante, preocupante también.

Reply to this comment

日 Comment by Morgan | 2008-03-01 14:33:28

Yo creo que vivimos las consecuencias de nuestros actos a nivel global. Es dificil relacionar el comportamiento de uno mismo con los grandes males del mundo, pero a veces hay que pararse a pensar si hacemos todo lo que podemos para vivir en un mundo mejor. Y esto no creo que signifique tener que marchar a un país pobre a ayudar a todo el mundo. Uno es más efectivo casi siempre en su entorno. Lo de echar una mano al de al lado, suele traer buenas consecuencias sobre todo si la ayuda es desinteresada y es un efecto cadena. Siempre habrá quien se aproveche, pero si actúas según tu forma de pensar, y pasas por el mundo dejando huella, estarás contribuyendo a un mundo mejor.

La angustia de ver los males del mundo no debe hacer desaparecer de tu cabeza las cosas bellas de la vida.

Un saludo,

Reply to this comment 


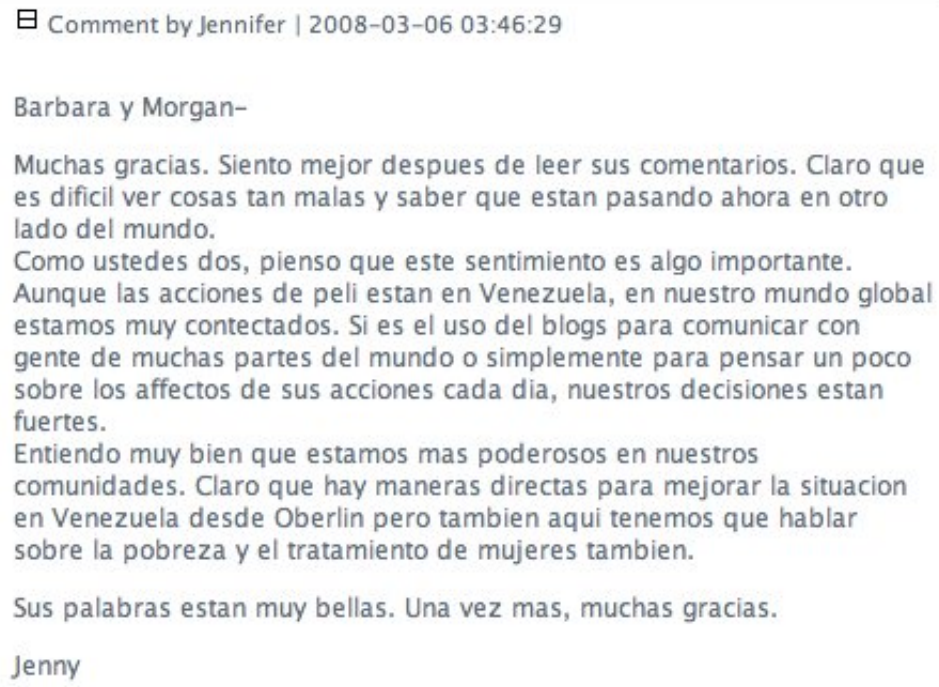

Reply to this comment

Comments from the community outside of our classroom happened with regularity. (Note: as a class we made a choice to have the blogs open to the world, but individual posts or entire blogs can be password protected to suit the users' comfort level.) Blogging on the inside and the outside of the Academy, I felt, provided the most remarkable and meaningful learning experiences for our class.

In this example, during a discussion of current events in on el blog central, a commenter named AMIGANORKA informs the class about her (or his, as we never knew for certain) feelings about the movie, María llena de gracia: 
Sawhill

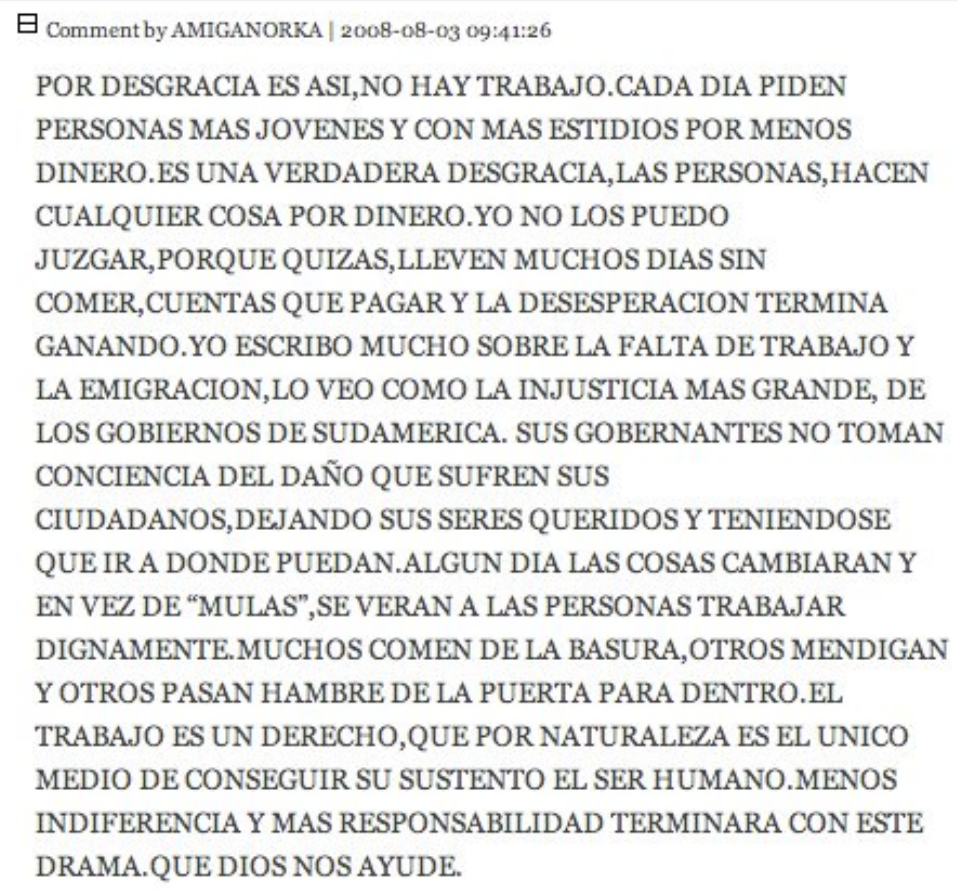

Later, after the semester was over, AMIGANORKA took it upon himself or herself to inform our blog about the release of Ingrid Betancourt, who had been held captive by the FARC for over 6 years. What is particularly astonishing about this comment is not only that it was posted, but that it arrived on the blog before the news broke in the regular US news media. 


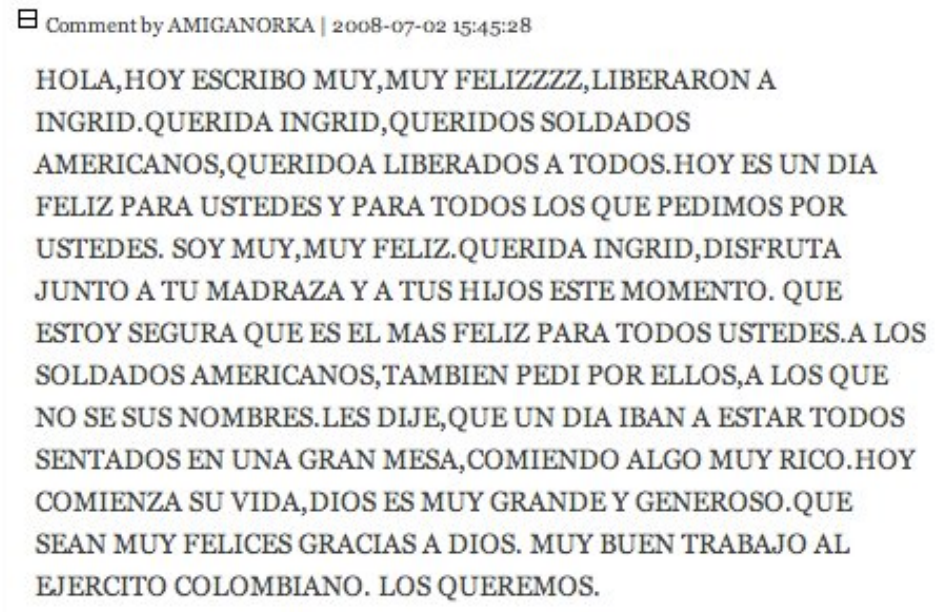

There were instances when students' posts did receive more pointed, even angry responses. In the case with a student named Karin, who wrote about a video he saw about Guatemalan refugees on YouTube, he received a series of pointed comments about his ignorant and ill-informed perspective on the situation. 


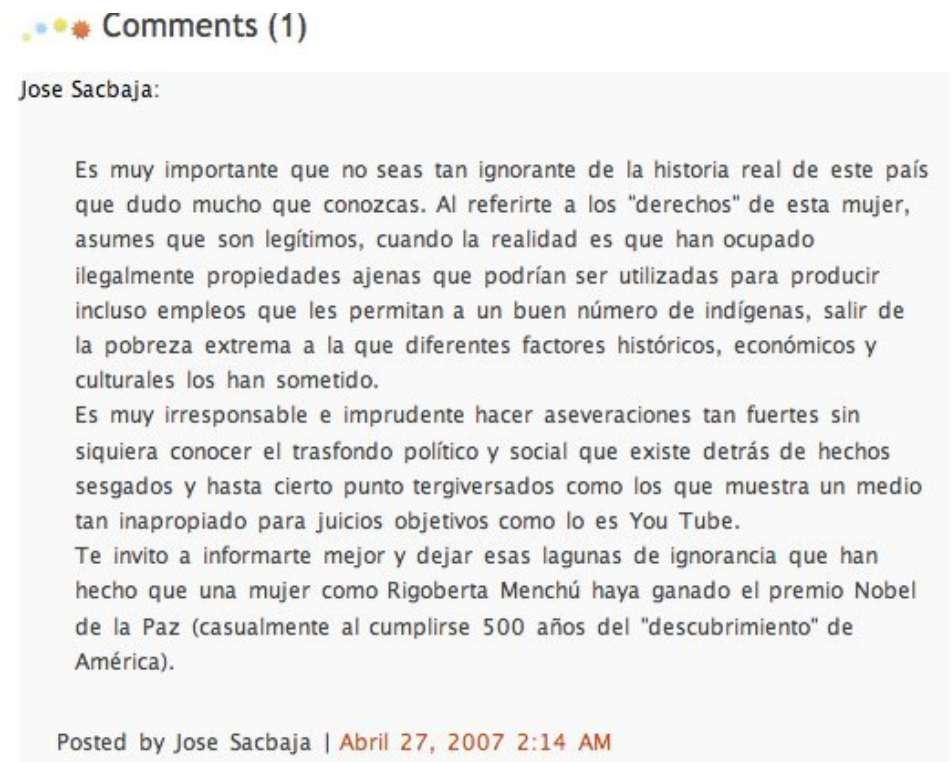

Karin elicited the support and the participation of his classmates in the creation of a proper response to his commenter, which in turn helped each of them anticipate how they might respond if a similar experience happened to them. This is only one example of how an event in one student's blog could serve as a learning opportunity for the rest of the class.

Perhaps one of the most astonishing moments happened the very first year I taught with blogs, and it proved to be an experience that galvanized the importance of keeping these blogs open and accessible to the outside world. Evie was a student who had spent a semester in Ciudad Juarez, studying and volunteering for a program called Casa Amiga, a resource center for women who worked in the maquiladoras. While Evie was in Juarez, she became aware of the hundreds of young women that had been violated and killed - a situation that had received very little attention in our country.

Evie used her blog to write about her experiences in Juarez, about the maquiladoras, and about the killings. She posted images of monuments to the femicides that she had seen while in the country. She recorded Skype ${ }^{\oplus}$ calls with her associates at Casa Amiga and posted them to her blog. Her blog not only recounted her experiences, it provided her with a way to explain to her classmates and others about what she had seen, felt, and heard in a place that was so very different from Oberlin.

Two remarkable things happened as a result of Evie's blog. First, her photos were discovered on the web by a group that was writing a book about the femicides and her images were subsequently published in that book. But most remarkably, was how Evie's blog, in the eyes at least one family who had lost a daughter on the border, became a resource and a sounding board. The following image provides an excerpted comment: 


\title{
LOS COMENTARIOS
}

\begin{abstract}
Eva de casa amiga, Te escribo esta carta para que insistamos ante la camara de diputados sobre la reforma al articulo 18 constitucional para que los delitos graves cometidos por los menores de edad, sean castigados de acuerdo a su gravedad. soy Mamá de Brenda Lerma Pineda, les redacto una carta esperando la hagan llegar al congreso de su estado y a todos los congresos de los estados de la republica. espero su contestación, comentarios y respuesta, mil gracias atentamente Miguelina pineda de Lerma.

nuevamente gracias por su espasio.
\end{abstract}

CARTA ABIERTA PARA TI.

QUE LA MUERTE DE MI HIJA NO QUEDE IMPUNE.

Han pasado 9 meses del asesinato de mi hija BRENDA LERMA PINEDA. Una chica de 17 años, sana, tranquila, buena niña, estudiante de preparatoria, con muchas ilusiones y planes para su vida futura. El día 21 de octubre mi hija, fue encontrada muerta, acuchillada, violada, degollada y con mas de 40 puñaladas, le arrebataron su vida sin piedad y de la forma más cruel y sanguinaria.

El 11 de noviembre del 2005 se capturaron 3 de los asesinos, y dan por finalizada la investigación. Sus declaraciones son diferentes de cada uno de ellos. En la reconstrucción de hechos no mencionaron los dos orificios de aguja hipodérmica que se encontraron en el ante brazo de mi hija. (el cuerpo fue encontrado cerca del pueblo en un cañaveral)

This family came to Evie's blog to ask for help, support, connections, and compassion. Through her blog, Evie became an advocate and an ally for a family whom she will never meet, and yet with whom she forged an extraordinary connection.

The question often arises as to whether blogging with the outside world creates an unhealthy fascination, even an "exotification" of the "other" through these tools. However, I would argue the opposite tends to happen. Blogs are primarily text-driven. Generally there are no visual or auditory cues. Thus, it is through the text of the blog that students become attentive to the nuances and the subtleties of written language. It is also through reading blogs that students learn to be attentive to cultural differences and learn how a well-intentioned but potentially insensitive blog post might be read differently in different cultures. It has been my experience that through blogging with others outside of the classroom, my students have discovered common points of reference and shared areas of interest and passion. They have found that recognizing diversity in voices does not meaning just identifying differences, it also means finding common ground.

Blogs, in my class, gave my students with an opportunity for meaningful contact with native speakers about topics that interested and intrigued them, and in turn allowed them to dig deeply into the content discussed and stretch their language abilities beyond what a traditional conversation class might 
have allowed.

An excerpt from an essay by one of my students about his experiences with blogs in Spanish class: It's hard to get into a Conservatory, let alone when you come from a state like Kentucky and are lucky to have a music program at all. Thanks to an online curriculum from a major university, I was able to teach myself about 20th century music-yet, I never gave anything back. Until 2007. [Through the blog in Spanish 305], I began to try to use my resources to help others in the effort to learn -and- teach.

My blog seeks to introduce "important" contemporary music alongside more modern works and even some random outbursts of early and popular music. Entirely in Spanish (making it harder to update, but also demanding I keep working towards Spanish proficiency), I post about composers, with biographical information, some notes for listening, and excerpts of major pieces that I edit myself to fit copyright laws.

Has my blog had effect? A resounding yes. [During Spanish 305] my blog was featured in an article on education and many music teachers in Argentina have written me thanking me for a powerful educational tool to use in their classrooms in teaching things like Impressionism. It was another comment like this that brought my blog back to life- knowing that my contribution never dies, even when I can't write. ${ }^{2}$

\section{Modeling Effective Practice while Mediating Institutionalized Fear}

Is this risky and irresponsible teaching? By blogging "out there" and not just "in here," are we putting our students at risk of predators, exposure, breaches of confidentiality, and other dangers? I would argue that this is not risky if the teacher understands the tools. It is the teacher's responsibility to guide and explain the potential pitfalls and problems of these tools to the students. The most effective way for this to happen is for the teacher to use these tools in his or her own personal collaborations, connecting with his or her own communities of learning, exploring in advance the online, interconnected communities of educators who use social software to extend their own classrooms.

An example of an educator using tools in her own scholarship can be seen in the example of Dr. Laura Blankenship who relied upon her blogging community to provide feedback, support, critiques in the completion of her dissertation. Laura writes: Nothing that I've accomplished in the last 3-5 years has been accomplished on my own. My dissertation, perhaps one of the most individual of endeavors, was read by blog friends and face-to-face friends and advisers. People commented on the ideas I threw out on the blog. I emailed people and asked for help, for resources, to play a sounding board. I used this blog tokeep me motivated and honest. Even in work, I rely on colleagues, both local and remote to help me figure out WordPress, find new tools, articles to read, and ideas to think about. (Blankenship 2005)

Tools such as blogs and other social communication software programs also challenge our institutions' policies for security and control. Many of our institutions prefer that web-based learning remain behind a password, a firewall, or a course management system. The authentic deep learning that can be accomplished "out there" is made impossible, as is the ability for outsiders to come "in here" to augment and enrich our students' classroom learning. There is an evolving disjunction within many of our institutions between the task of maintaining a secure and closed network and the exploration of an open and ever expanding community of global learners sharing multiple perspectives and practices.

We as educators now also need to be advocates. We also need to build bridges between the academic side of education and the IT side of the enterprise. While both entities would say they support the 
academic mission of any school, they clearly have different ideas as to what "support" means. We need to speak honestly and passionately with our IT officers and work with them. We must advocate for the connections that these outward-facing, unblocked, password-free connections can provide for language teaching and learning.

Alan November wrote in his blog If we could get past our fear of the unknown and embrace the very tools we are blocking (which are also essential tools for the global economy) then we could build much more motivating and rigorous learning environments. We also have an opportunity to teach the ethics and the social responsibility that accompany the use of such powerful tools. Indeed, our often deeply ingrained fear of letting go of control, even in the slightest sense, quite often limits our ability as teachers and technologists to see the promise that social software might provide.

It is at this juncture - the place where learning technology and language pedagogy, where the teacher and the students and technologies all intersect - it is here where the language learning technologist becomes an indispensable advocate for appropriate and effective uses of social technologies. It is this person who can help faculty, students, and IT administrators negotiate the myriad of fears, anxieties, and misconceptions that come with the adoption of new tools to promote effective language learning. It is no longer possible to teach the way in the way in which one was taught. That simply will not work any further given the forces that are at play in our world today.

Teaching with social software is about disrupting the status quo, and for the sake of learning, letting go of the notion that teachers can control and manage learning and instead embrace the possibilities of what can happen when we throw open the doors and windows of our classrooms, invite in the outside world, and challenge our traditional classroom practices. We fear losing control. What do the more student-centered strategies all have in common? They all represent shifts in the nature of authority in the classroom. They require us to move away from the idea that information may be transferred intact from expert to novice. Instead, they ask us to move toward the model of the student as self-teacher, recognizing that knowledge is of necessity constructed in the mind of the learners as they seek to reconcile new knowledge with mental models they've built based on former experience. (Hodges 2006)

As language educators and technologists, we need to be ready to accept that change is hard, but change is imperative if we are to meet the needs of our students as they prepare to enter a rapidly changing world outside of the Academy. Fear is a natural by-product of change, but fear should not prevent us from going forward. Our job, now more than ever, is to model effective and responsible teaching and technological practices for our colleagues. To quote bell hooks: [M]any teachers who do not have difficulty releasing old ideas, embracing new ways of thinking, may still be as resolutely attached to old ways of practicing teaching as their more conservative colleagues. That's a crucial issue. Even those of us who are experimenting with progressive pedagogical practices are afraid to change.

\section{Conclusion}

Ewan McIntosh stated in a talk for The Royal Society of Edinburgh: As language educators in the 21st century, we must either change... or die. ${ }^{3}$ To learn a language with the assistance of social software and communicative technologies in the 21st century classroom, we will provide our students with a sense of cohesiveness that our traditional learning space, a classroom enclosed by four walls, simply cannot provide. By welcoming and celebrating a multiplicity of perspectives, a cacophony of voices, different and differing worlds, cultures, and languages we not only improve our teaching, but we also better 
prepare our students for the world that awaits them. We must do this not with a blind sense of urgency or because we are seduced by the tools, rather, we must adopt technology with a careful sense of purpose. We must articulate for ourselves, and with the help of our students, what we want the ultimate outcome of our language learning objectives to be, and then choose tools that will facilitate that objective. Our response to the need for change in our teaching is to neither shy away from nor race to technology, but rather to be mindful that no two of us lives in the same information age (Bruce 2003) as we balance our teaching today between the way it has been in the past and how it must be in the future.

In the four years that I have used social software in the classroom, I have come to realize that online communication practices, brought carefully and conscientiously into even the most traditional, silo-ed classrooms, can enhance language teaching and learning. These practices also provide a new and compelling way to encourage collaborations and conversations with our IT officials about the "hows and whys" of learning in the Academy and the Internet.

Our emerging role as teachers and technologists in the 21st century is to prepare ourselves, our colleagues, our schools and our classrooms for the linguistic and cultural realities of the teaching in a world where everyone and everything is connected, or as Theodor Nelson calls it, intertwingled. As language teachers and technologists we must build bridges, both within our institutions and outside of our classrooms, in order that we may support active and relevant learning within the Academy and with the outside world, with the intended outcome of better preparing our students for the diverse and complex world that awaits them after graduation.

Notes

1. For the purpose of this article, the terms social software, disruptive technologies, and Web 2.0 tools will be used interchangeably and will refer to technologies that promote community building, asynchronous and synchronous communication and interaction between users (i.e. blogs, Skype ${ }^{\oplus}$, wikis, Twitter ${ }^{\oplus}$, Flickr ${ }^{\oplus}$, etc).

2. Hanson, Sean in an email to me in October 22, 2008. This was an excerpt from his application essay for a scholarship.

3. http://www.lingo24.com/language translation forum/viewtopic.php?t=176

\section{References}

Association of American Colleges and Universities, \& National Leadership Council (U.S.) (2007). College learning for the new global century: a report from the National Leadership Council for Liberal Education \& America's Promise. Washington, D.C.: Association of American Colleges and Universities.

Blankenship, L. (2008, July 25). Web 2.0 and the future of... Message posted to http://geekymom.blogspot. com/2008/07/web-20-and-future-of.html

Bruce, C. B. (Ed.) (2003). Literacy in the information age: Inquiries into meaning making with new technologies. Newark, Delaware: International Reading Association.

Duderstadt, J. J. , Atkins, J. J. \& Van Houweling, D. E. (2002). Higher Education in the Digital Age: Technology Issues and Strategies for American Colleges and Universities. American Council on Education/Praeger series on higher education. Westport, Conn: Greenwood Press.

Gee, J. P. (2004). Situated Language and Learning: a critique of traditional schooling. Literacies. New York: 
Routledge.

Haney, D. P. (2007, February 09). Millennial, but Not Really Different [Letter to the editor]. Chronicle of Higher Education. http://chronicle.com/weekly/v53/i23/23b01401.htm

Hodges, L. C. (2006). Helping Faculty Deal with Fear. In Chadwick-Blossey, S. \& Robertson, D. R. (Eds.), To improve the academy. resources for faculty, instructional, and organizational development Vol. 24. Bolton, MA: Anker Publishing Co.

hooks, b. (1994). Teaching to Transgress. New York: Routledge Press.

Lévy, P. (1997). Collective Intelligence. Cambridge, MA: Perseus Books.

Lohnes, S. \& Kinzer, C. (2007). Questioning assumptions about students' expectations for technology in college classrooms. Innovate 3(5). Retrieved April 9, 2008, from http://www.innovateonline.info/ index.php?view=article\&id=431.

MLA Ad Hoc Committee on Foreign Languages, Modern Language Association (2007). Foreign Languages and Higher Education: New Structures for a Changed World. Retrieved April 10, 2008, from http:// www.mla.org/flreport.

Nelson, T. (1974). Computer Lib/Dream Machines. In Wardrip-Fruin, N. \& Montfort, N. (Eds.), The New Media Reader, 2003 (pp. 301-338). Cambridge, Mass: M.I.T. Press.

Norton Pierce, B. (1995). Social Identity, Investment and Language Learning. TESOL Quarterly 29(1): 9-31.

November, A. (2007, June 15). Banning Student 'Containers'. TechLearning. Retrieved April 9, 2008, from http://www.techlearning.com/showArticle.php?articleID=196604487.

Omaggio Hadley, A. (1993). Teaching Language in Context. Boston, MA: Heinle and Heinle.

Payne, J. S. \& Whitney, P. J. (2002). Developing L2 Oral Proficiency through Synchronous CMC: Output, Working Memory and Interlanguage Development. CALICO Journal 20(1): 7-32.

Siemens, G. (2007). Spaces and Structures of Tomorrow's Learning. digital Cultural Content Forum (dCCF) 2007. Retrieved April 9, 2008, from http://www.chin.gc.ca/English/Knowledge-Exchange/ transcript day george.php.

Smith, F. (1998). The Book of Learning and Forgetting. New York: Teachers College Press.

Swaffar, J. \& Arens, K. (2005). Remapping the Foreign Language Curriculum: An Approach through Multiple Literacies. New York: Modern Language Association of America.

Yankelovich, D. (2005, November 25). Ferment and Change: Higher Education in 2015. Chronicle of Higher Education 52(14): B6. Retrieved April 14, 2008, from http://chronicle.com/weekly/v52/i14/ 14b00601.htm.

Young, J. R. (2008, May 09). The Extracurricular Charm of Blogging: an Interview with Kelly Sutton. Chronicle of Higher Education. Retrieved April 14, 2008, from http://chronicle.com/weekly/v54/ i35/35a01102.htm. 